\title{
アルギニン拈よびデキサメサゾン負荷後のケトーシス 牛の血漿脂質と関連ホルモンの変動
}

\author{
木村容子*1) 若松脩継*2) 関根淳仁*2) 元井臀子*3) 本好茂一*4)
}

（昭和 59 年 1 月 20 日受理）

\begin{abstract}
Responses of Hormones Related to Glucose Metabolism and Lipid Components in Cows Affected with Ketosis after Treatment with Arginine or Dexamethazone Үонко Kimura (Institute of Animal Health, Prefecture of Gumma, Gumma 371-01) et al.

\section{SUMMARY}

Arginine treatment was performed on four cows with ketosis and two healthy cows. Other cows were treated with dexamethazone. Each cow received $320 \mathrm{~g}$ of arginine or $20 \mathrm{mg}$ of dexamethazone into the jugular vein. After infusion, blood samples were collected 9-13 times from this vein to determine pancreatic insulin (IRI) and glucagon (IRG), and blood glucose and lipid components.

Low responses of IRG and IRI were observed on two of the four cows affected with ketosis. They were also observed in the healthy cows and the other two affected cows after having recovered from ketosis. One of the affected cows showed extremely high levels of IRG and IRI after arginine treatment. Response of IRI was later than a rise in glucose in the affected cows treated with dexamethazone, as compared with the healthy ones.

From the results mentioned above it seemed that ketosis might be related to hormonal disturbance in glucose metabolism.

要約

搾乳牛に発生するケトーシスの病態を内分泌面より検討する目的で, 糖代謝に関与するホルモン の変動を調查した.

初診時に尿中ケトン体が(十)から(冊)検出されたホルスタイン種搾乳牛を供試牛として, アルギ ニン一塩酸塩 (Arg.) を 4 頭に, デキサメサゾン (Dex.) を 2 頭に負荷し, 注入直後を中心に 9 13 回採血して経時的にホルモン, グルコース (Glu.) と血漿脂質成分の変動を測定し, 健康対照牛の 值と比較した.

Arg. 負荷後の病牛のホルモン応答は, インスリン (IRI) と膵グルカゴン (IRG) の上昇が著明で なかったタイプ 2 例, IRG と 11-OHCS が過剩応答を示したタイプ 1 例と健康牛に類似して負荷 直後にIRI とIRGが著明に上昇したタイプ 1 例が認められた. 前者 2 例についてケトーシスが治 癒した時点で Arg. を再度負荷したところ，健康牛と同様な応答パターンを示した. Dex. 負荷試験 では, 健康牛は Glu. が 24 時間目をピークとする变動を示し, Glu. の増加に伴って IRI の上昇が 観察されたが, 病牛は, 健康牛と同様の Glu. の変動パターンを示したものの IRI の反応が遅れる 傾向にあった.

以上の結果から, ケトーシスは中間代謝過程に和ける糖源物質の不足に加えて, 糖代謝に関係あ るホルモンの失調が関与しているものと推察された。

搾乳牛に発生するケトーシスは典型的な production

*1) 群馬県家畜衛生研究所 (群馬県勢多郡富士見村小 暮2416)

*2) 群馬県経済連邑楽牛乳処理場（群馬県邑楽郡邑楽 町赤堀151)

*3) 農林水産省家畜衛生試験場（茨城県筑波郡谷田部 町観音台3-1-1)

*4) 日本獣医畜産大学（東京都武蔵野市境南町 1-7-1） disease の一種で, エネルギーの需要と供給の不均衝に 由来するといわれている4,5,8,10,20). ケトーシスに関する 研究 ${ }^{6,7,19)}$ や報告 ${ }^{13,17,18)}$ は数多く, 現在までのところ乳牛 の栄養とケトーシスの発生の関連については明確にされ ている ${ }^{1 \sim 3,16)}$. しかし, ケトーシスの適確な病態の分類 法と治療法については不明な点が多く, さらに検討の余 地がある、筆者らは，ケトーシスの牛の糖代謝に関与す 
るホルモンの変動を観察することによって,ケトーシス の病態を内分泌面より検討し，これに基づいてより適切 な治療法を開発するために, 調査を行っている.

今回は, ケトーシスの牛にアルギニン㧤よびデキサメ サゾンを負荷し，糖質および脂質代謝に関連するホルモ ン，グルコースおよび血漿脂質成分の応答について検討 したので，その概要を報告する.

\section{1. 材料および方法}

\section{1) 供試牛と供試薬剤}

供試牛は一般農家に飼養されていたホルスタイン搾乳 牛で, 1981 年 7 月から 1982 年 3 月までの間に, 初診時, 食欲不振等の臨床症状のほかに，尿中ケトン体が $(H) 〜$ （冊）検出されたものを用いた。 アルギニン負荷試験は, アルギニン一塩酸塩 (以下, Arg. と略) $320 \mathrm{~g}$ を 4 頭 （K1〜K4）に，デキサメサゾン負荷試験は，デキサメ サゾン (以下, Dex. と略) $20 \mathrm{mg}$ をリンゲル液 $500 \mathrm{ml}$
に溶解したものを 1 頭（K5）に, Dex. $20 \mathrm{mg}$ をプロピ オン酸ソーダ，ソルビット等を含む製剤プロチオン 500 $\mathrm{m} l$ に溶解したものを 1 頭（K6）にそれぞれ頸静脈から 負荷した. Arg. 負荷試験の対照として 2 頭の健康牛 (C 1, C 2）に, Dex. 負荷試験（K6）の対照として 1 頭 （C4）にそれぞれ試験牛と同様の薬剂を投与し，K5 の 対照 1 頭（C3）にはリンゲル液 $500 \mathrm{ml}$ のみを投与した (表 1). 各試験区の採材時間は表 2 に示したとおりで, 負荷直前, 負荷後 10 分, 20 分, 30 分, 60 分, 90 分, 120 分の注入直後を中心に 9〜13 回採材を行った. また, $\mathrm{K} 1$ および $\mathrm{K} 2$ には, ケトーシスが完全に治癒した分婏 後 3 カ月目に再度 Arg. 負荷試験を行った.

\section{2) 検 查 項目と方 法}

インスリン (以下, IRI と略) と萃グルカゴン (以下, IRG と略) はラジオイムノアッセイ・チャコール法, ハ イドロコーチゾン（以下，11-OHCS と略）は蛍光法に よる倉田氏変法で測定した. グルコース（以下，Glu.と

表 1 供試牛と供試薬 鼡

\begin{tabular}{|c|c|c|c|c|c|}
\hline 供試牛 & No. & 最終分婏月日 & （産次） & 尿ケトン体 & 供 試 薬 剂 （負荷量） \\
\hline $\mathrm{C}$ & 1 & 1981. 5.29 & （初産） & - & アルギニン一塩酸塩 $(320 \mathrm{~g})$ \\
\hline $\mathrm{C}$ & 2 & 1982. 1.10 & （3 産） & - & $\| \quad(11)$ \\
\hline $\mathrm{K}$ & $1^{*}$ & 1981. 6.17 & （4 産） & 册 & $(\|)$ \\
\hline $\mathrm{K}$ & $2^{*}$ & 1981. 6.12 & （初産） & $H$ & $(11)$ \\
\hline $\mathrm{K}$ & 3 & 1982. 3. 9 & （3 産） & 册 & $(I \prime)$ \\
\hline $\mathrm{K}$ & 4 & 1982. 2.12 & （4 産） & H & $(" 1)$ \\
\hline $\mathrm{C}$ & 3 & 1982. 1.2 & （2 産） & - & リンゲル液 $(500 \mathrm{~m} l)$ \\
\hline $\mathrm{K}$ & 5 & 1982. 1.16 & （3 産） & 册 & デキサメサゾン $(20 \mathrm{mg})+$ リンゲル液 $(500 \mathrm{~m} l)$ \\
\hline $\mathrm{C}$ & 4 & 1982. 2.10 & （4 産） & - & ( \\
\hline $\mathrm{K}$ & 6 & 1982. 2.28 & (3 産) & 冊 & $(" \prime)+11 \quad(")$ \\
\hline
\end{tabular}

注）*: K 1, K 2 はケトーシスが完全に治癒した分婏後 3 カ月目にアルギニン負荷試験を再度実施した

表 2 試 験 区 分と採材 時間

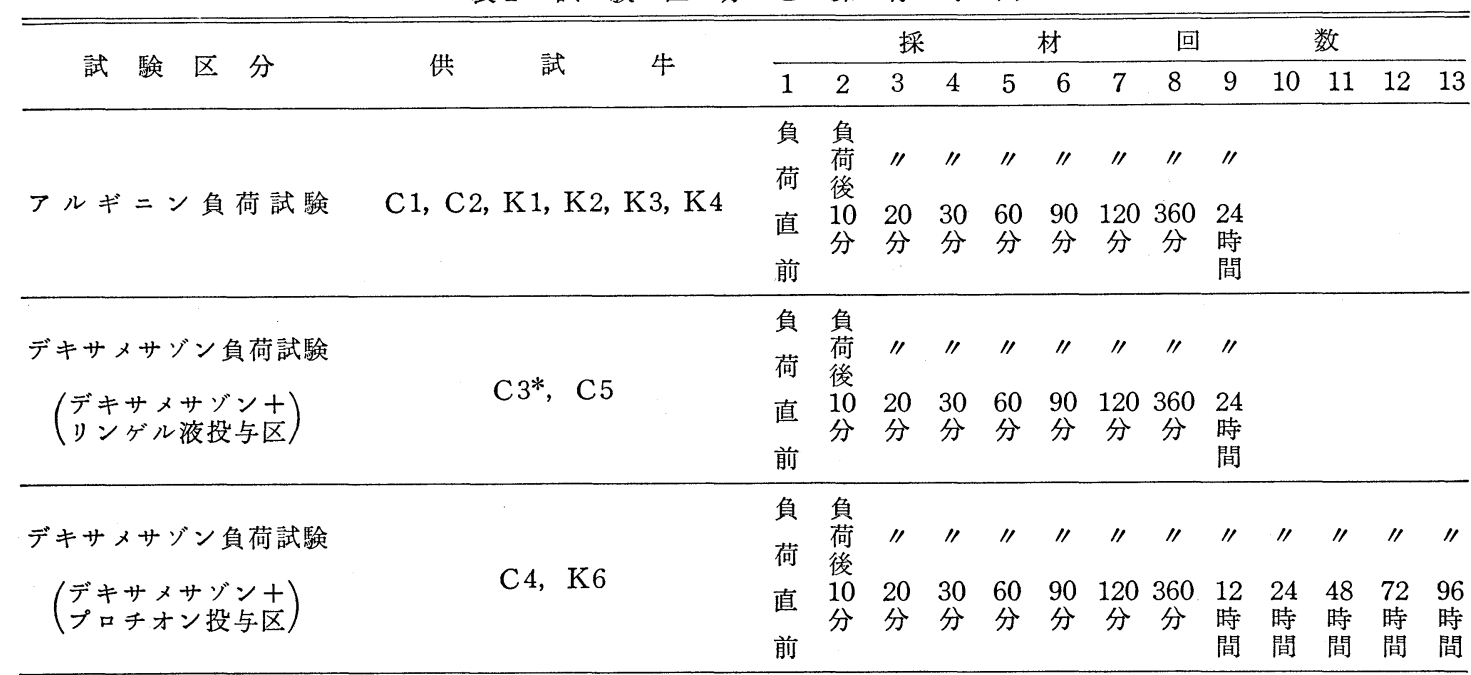

注）*：C 3 はyンゲル液のみ投与 
アルギニンおよびデキサメサデン負荷後のケトーシス牛の血漿脂質と関連ホルモンの変動

略), 総コレステロール(以下, T-chol. と略), HDLコレステロール (以下, HDL-chol. と略) は酵素法, 遊離脂肪酸（以下, NEFA と略）は ACS-POP 法, 中性脂肪（以下，TG と略）は酵素法で測定し，ア セト酢酸（以下，Acac. と略）および $\beta$-ハイドロキ 酪酸（以下， $\beta-O H B A$ 之略）は簡易分別定量法で 測定した.

\section{2. 成績}

\section{1）. 健康牛およびケトーシス牛に対するアルギニ ン負荷試験}

(1) 健康牛のホルモンと血液成分の変動パター ン：C1 扰よびC 2 の Arg. 投与後の血中 IRG, IRI 抢よび Glu.は 3 成分とも負荷後 10 分ないし 30 分 をピークに急激な上昇を示し，その後減少して IRG と IRI は 90 分から 120 分にかけて負荷前值にもど った. Glu. 多漸減し, C1は 90 分, C2 2120 分 でそれぞれ最低值 (C1 は $50.1 \mathrm{mg} / \mathrm{d} l, \mathrm{C} 2$ は 38.1 $\mathrm{mg} / \mathrm{d} l)$ を示したが， 24 時間目には負荷前值をで回 復した. C1 の 11-OHCS は負荷直後, 他のホルモ ンと同様に一過性の上昇がみられたが，C2 では著 変注認められなかった（図 1).

健康牛の血漿脂質成分は, いずれも Arg. 注入直 後に一過珄の減少が認められた（図 2).

(2) ケトーシス牛のホルモンと血液成分の変動パ ターン : 分娩後 10〜37 日の間に供試した K $1 \sim \mathrm{K} 4$

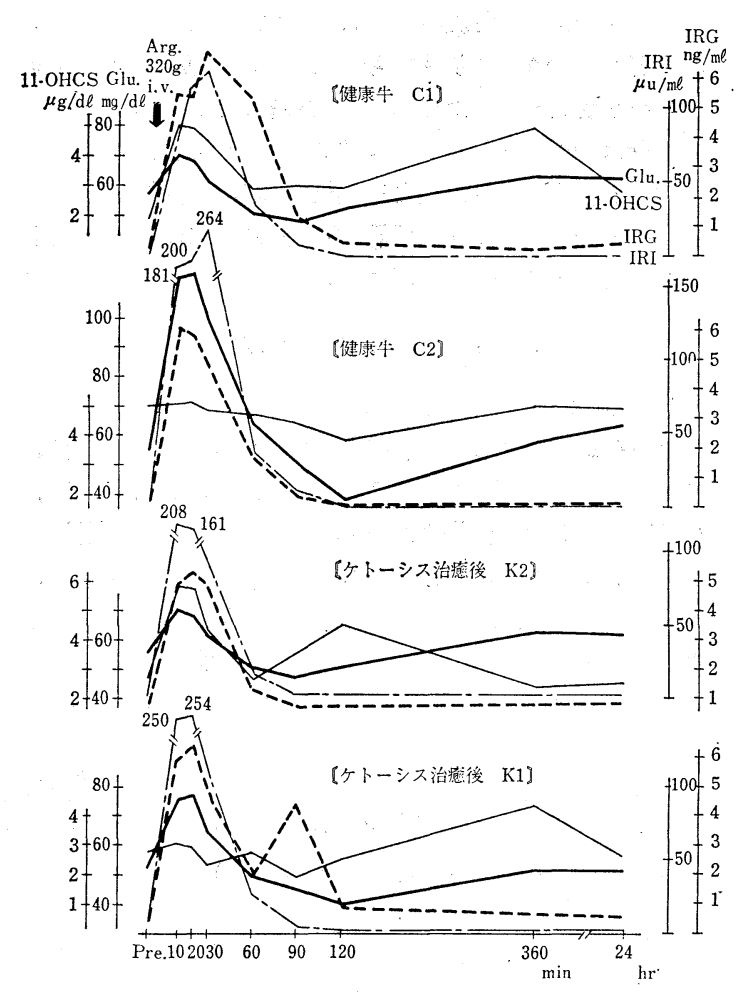

因 1 健康牛, ケトーシス治痛後のアルギニン負荷 によるグルコースとホルモンの応答

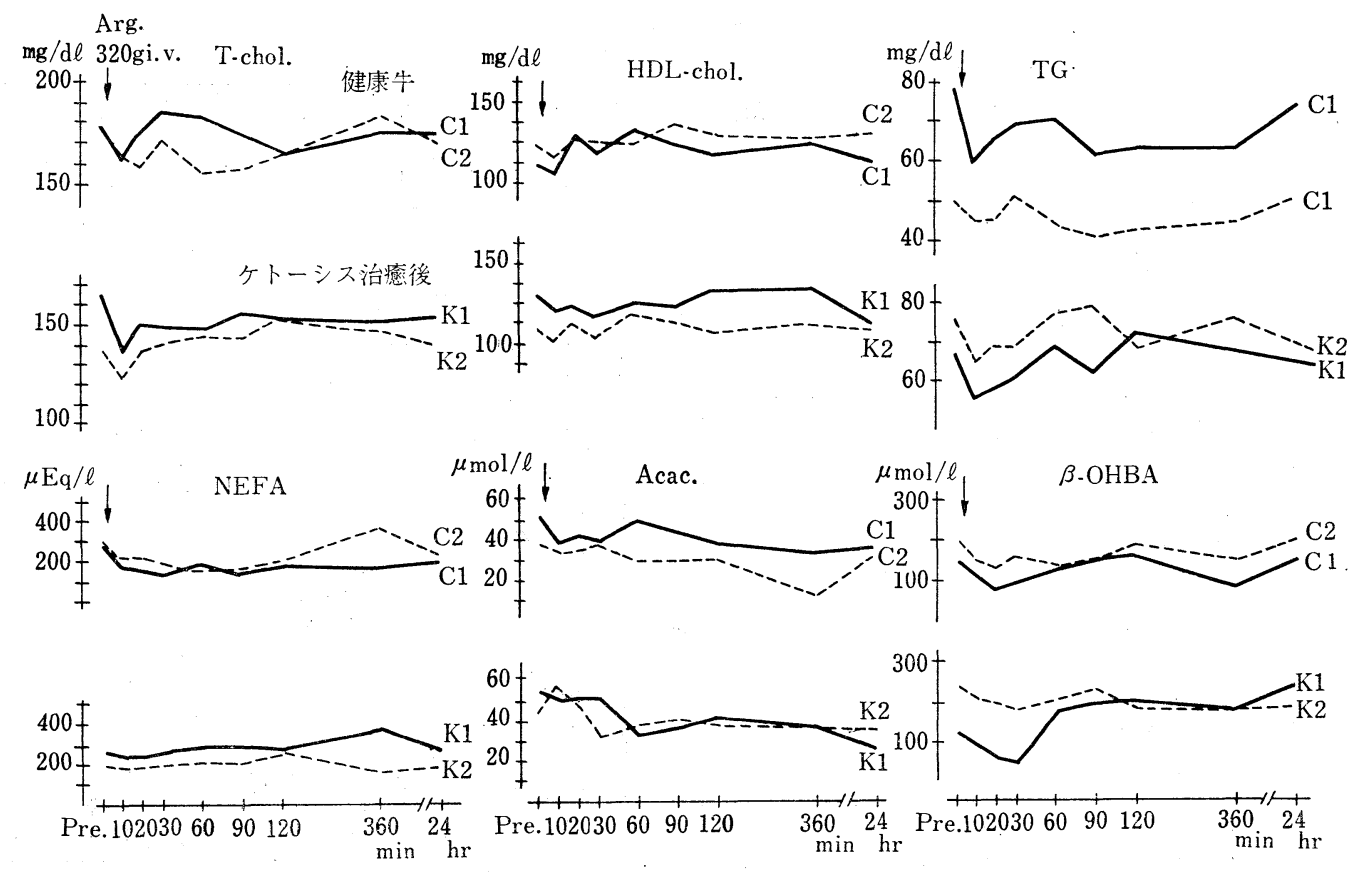

図 2 健康牛, ケトーシス治癒後のアルギニン負荷による血漿脂質の応答 
に対する Arg. 負荷後のホルモンと Glu. の応答を 因 3 亿示した. K1 特よび $\mathrm{K} 2$ は，負荷直後の血中 IRG の值がきわ低く，血中 IRI と Glu. は上 昇したるのの, 健康牛に比較するとその值は低かっ た. 両者の Glu. の最低値 (K1 は負荷後 360 分, $\mathrm{K} 2$ は 120 分）は K1 $32.7 \mathrm{mg} / \mathrm{d} l, \mathrm{~K} 239.3 \mathrm{mg} / \mathrm{d} l$ であったが，健康牛のように負荷前値以下には減少 しなかった. $\mathrm{K} 3$ は Arg. 負荷後, 血中 IRG と 11OHCS が著しく上昇し, IRG は 20 分と 60 分に 2 峰性のピークを有する応答が認められ，11-OHCS は負荷直後から 360 分まできわめて高い値を維持し た. K3 は負荷直後, 血中 Glu. の増加がほとんど 認められず, 他の 3 症例之は異なって, 負荷後 24 時間目飞負荷前值 $(25.3 \mathrm{mg} / \mathrm{d} l)$ の 2 倍以上の值 $(57.4 \mathrm{mg} / \mathrm{d} l)$ になった. 血中 IRI は負荷前から 24 時間目まで核とんど変動しなかった. $\mathrm{K} 4$ の Arg.負 荷による血中 IRG, IRI 拈よび Glu. の応答は, 健 康牛のパターンに類似していた。

ケトーシス牛に対する Arg. 負荷後の血漿脂質成 分は, 健康牛の上うな一定の変動パターンがみられ ず，かつ個体による変動が著しかった．とくに血中 IRG と 11-OHCS が著明に上昇した K3 の NEFA は，負荷直後から急激に増加した. また，Acac. は 負荷直後に一過性の減少が認められたるのの, その 後は影著な増加を示した. $\beta$-OHBA は負荷直後よ り異常な高値を示し， 6 時間後までその值を維持し
K1
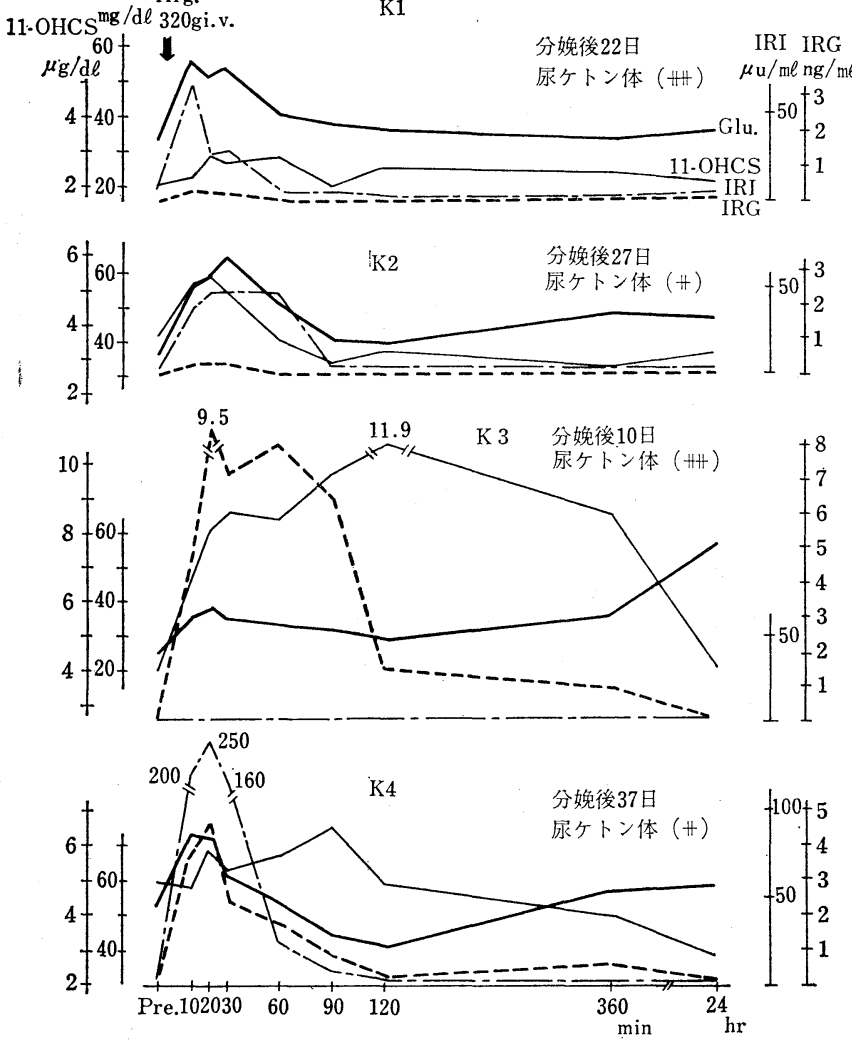

因3ケトーシス牛のアルギニシ負荷によるグルコース とホルモンの応答
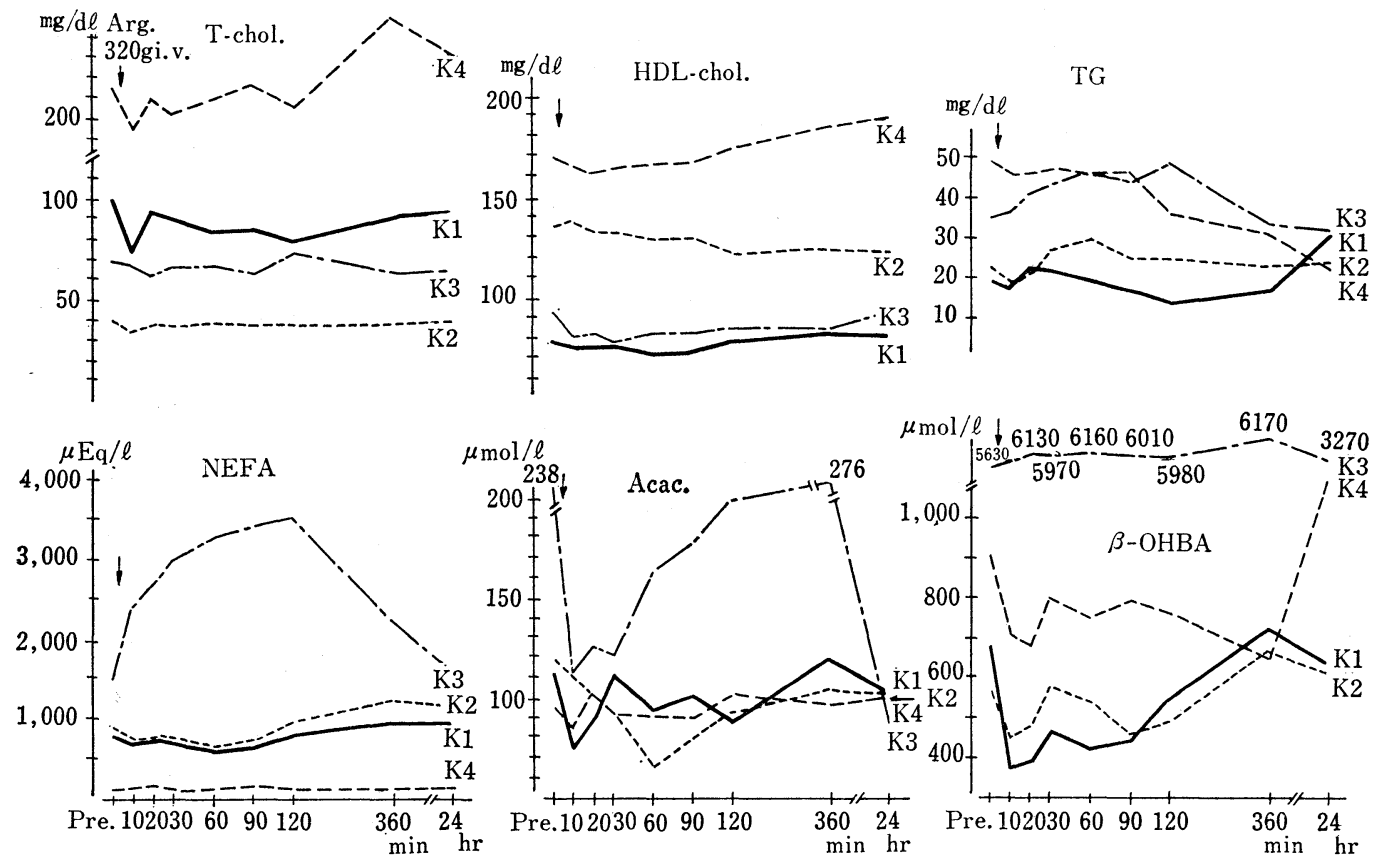

図 4 ケトーシス牛のアルギニン負荷による血漿脂質の応答 
た. しかし, Glu. が負荷前値の 2 倍以上にまで上昇した 24時間後には Acac., $\beta$-OHBA とも負荷前值の約 1/2 の 濃度に低下した（図 4 )。

(3) ケトーシス治癒後のホルモンと血液成分の変動パ ターン：ケトーシスが治癒した後の $\mathrm{K} 1$ および $\mathrm{K} 2$ に, 再度 Arg. を負荷したところ, 各成分の変動カーブは治癒 前と異なり健康牛の変動パターンに近くなり, とくに治 療前に応答がきわめて低かった IRG は上昇した(図 1).

ケトーシス治癒後の血漿脂質成分 では K1 と K2 の間の個体差がほと んどなくなり, 健康牛のパターンと 同様に Arg. 負荷直後, いずれの成 分に和いても一過性の減少が認めら れた(図2).K1，K2 とも，治瘉後 の Arg. に対する応答パターンを健 康牛と比較する意味で図 1 および図 2 に示した。

（4）アルギニン負荷時の腪グルカ ゴン/インスリン比 : Arg.負荷時の 健康牛の IRG/IRI 比は $74 \sim 2,000$ の範囲にめったＩRG の応答が低 かった K1 と K2 の比は 0.13〜156 の範囲にあり, 健康牛に比較すると その值は低く，また，IRI が無応答 であった K3 では 40～38,000 の範 囲できわめて大きな変動を示した. 比較的健康牛に近いパターンを示し た K4 の比は，20〜1,200の範囲で
Glu. $\mathrm{mg} / \mathrm{d} \ell$

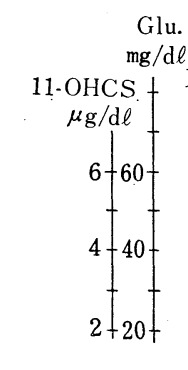

あった. Arg. 負荷時の IRG/IRI 比と Glu. の相関は -0.320 で, $\beta$-OHBA との相関は 0.771 であった.

2）健康牛およびケトーシス牛に対するデキサメサゾ 負荷試験

（1）健康牛のホルモンと血液成分の変動: Dex. 負荷 試験の対照として用いたC 3 にはリンゲル液のみを投与 したが，この時の IRG，IRI および Glu.はほぼプラト 一な值で推移し，11-OHCS は投与直後に一過性の上昇
『ケトーシス牛
ゲル $500 \mathrm{mli.v.}$

Dex. $20 \mathrm{mg}$ +リンゲル $500 \mathrm{~m} \ell$ i.v.

K5）分娩後20日 尿ケトン体 (H)

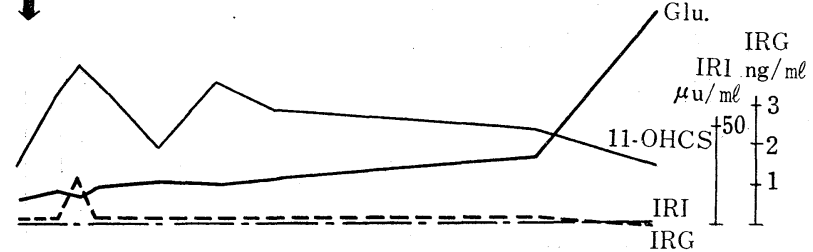

〔健康牛 $\mathrm{C} 3$ 〕

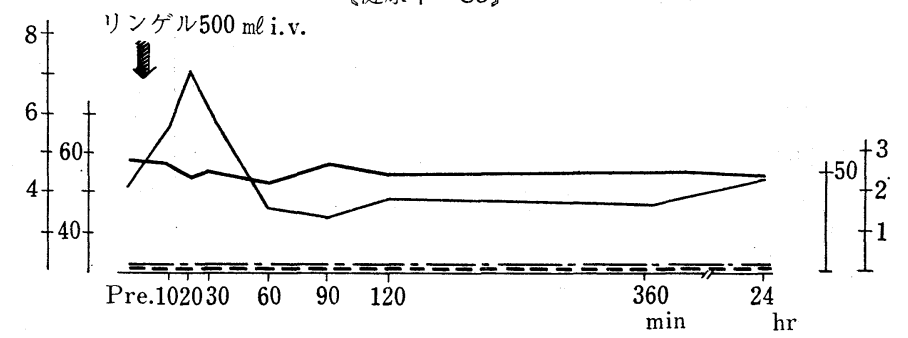

図 5 ケトーシス牛のデキサメサゾン負荷によるグルュース とホルモンの応答(1)

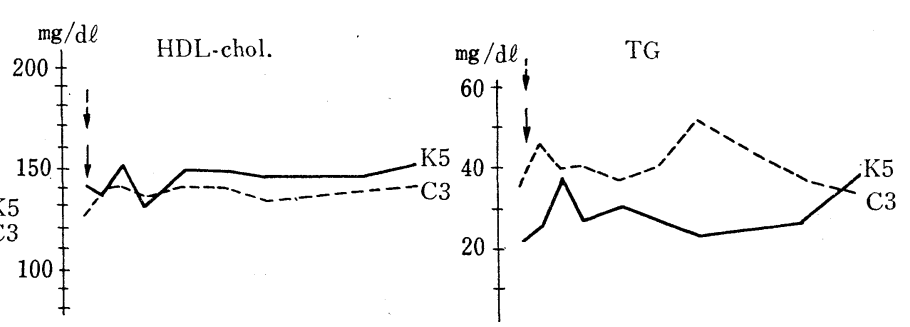

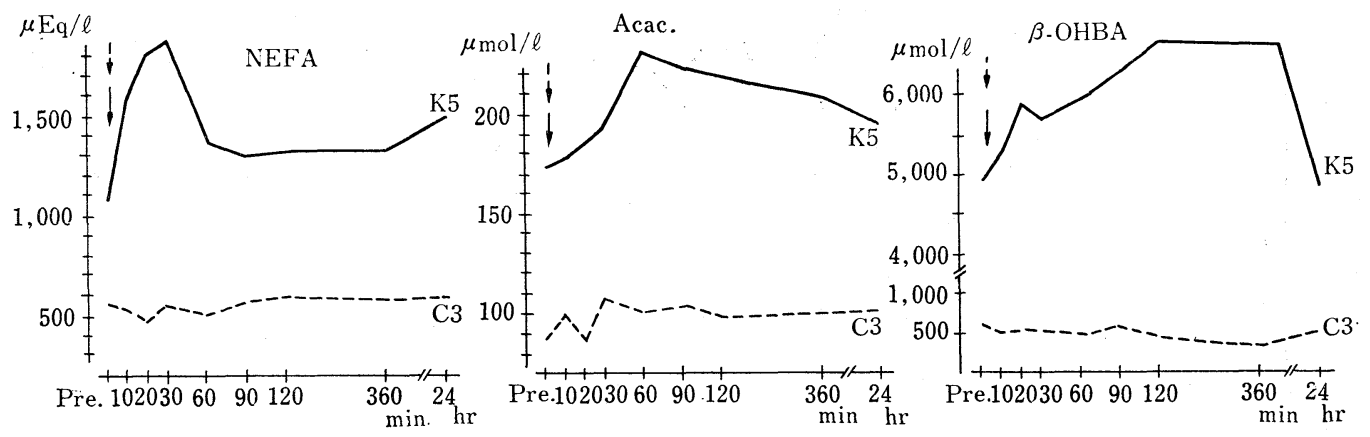

図 6 ケトーシス牛のデキサメサゾン負荷による血漿脂質の応答(1) 
を示した（図 5).

C 3 の血漿脂質成分の変動は図 6 に示したと扣り，Tchol. と TG に各々一過性の減少と増加が認められた.

同一薬剤を投与したK6 の対照の C 4 は, Glu. が Dex. 負荷後 20 分と 24 時間に 2 峰性のピークを示し, 負荷直 後の Glu. の増加に一致して IRI の上昇が認められた. IRI は 60 分には負荷前值にもどったが, Glu. の 2 回目 の増加に伴って 120 分後から再び上昇を示し, 12 時間 目にピークに達してから潮次減少し，72時間目に負荷前 值にもどった. C4の IRG は,

Glu. の増加に一致してわずかな 上昇がみられた（図7）。

C 4 の血漿脂質成分では, TG と $\beta$-OHBA が Glu. の 2 回目の ピ 一クと同一時期に一過性の増加が 認められた（図8).

(2) ケトーシス牛のホルモンと 血液成分の変動 : Dex.負荷による K5 の IRG, IRI はほとんど変動 がなく, 11-OHCS は負荷後 2 峰 性の上昇を示した. また, Glu.は， Dex. 負荷後 24 時間目に負荷前值 $(26.0 \mathrm{mg} / \mathrm{d} l)$ の 3 倍にも達する 顕著な増加 $(73.4 \mathrm{mg} / \mathrm{d} l)$ が認め られた (図 5 ).

K5 の血漿脂質成分は, NEFA,
Acac. 乱よび $\beta$-OHBA に拈いてDex. 投与後一過性また は持続的な上昇がみられ, Arg. 負荷時の K 3 の変動パタ ーンに類似していた（図6）.

K6 では, Dex. 投与後 Glu. が C 4 と同一パターンで 変動した. しかし, IRI は負荷直後の Glu. の上昇に伴 ら応答は認められなかったが，24 時間後の Glu. の増加 に対する IRI の応答は 48 時間後にみられた. K6 の IRG は, 負荷直前から負荷後 96 時間まで汪とんど変動 がなかった（図 7 ).
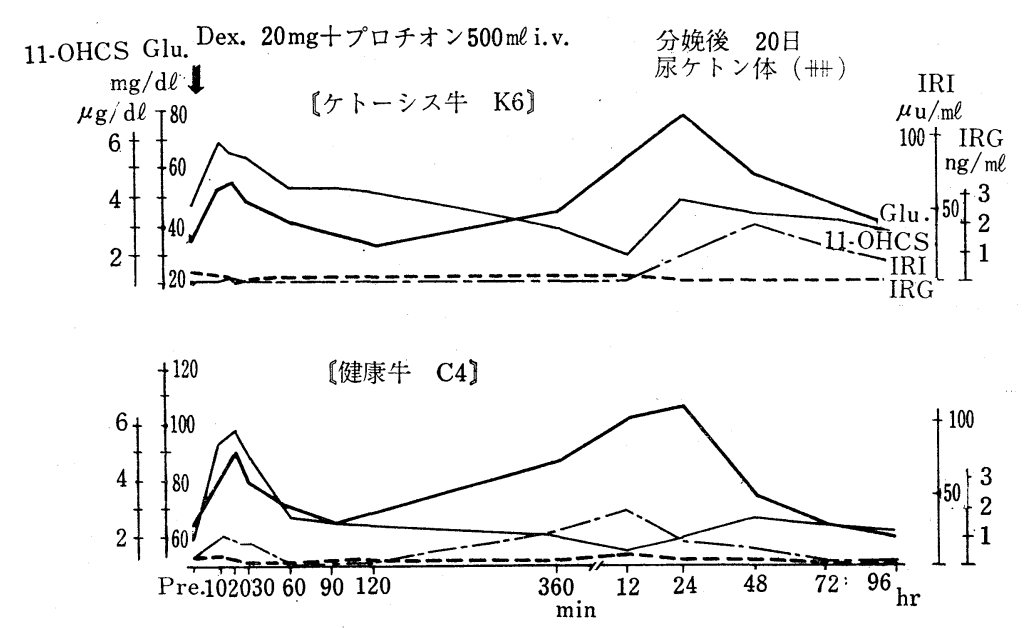

図 7 ケトーシス牛のデキサメサゾン負荷によるグルコースと ホルモンの応答(2)

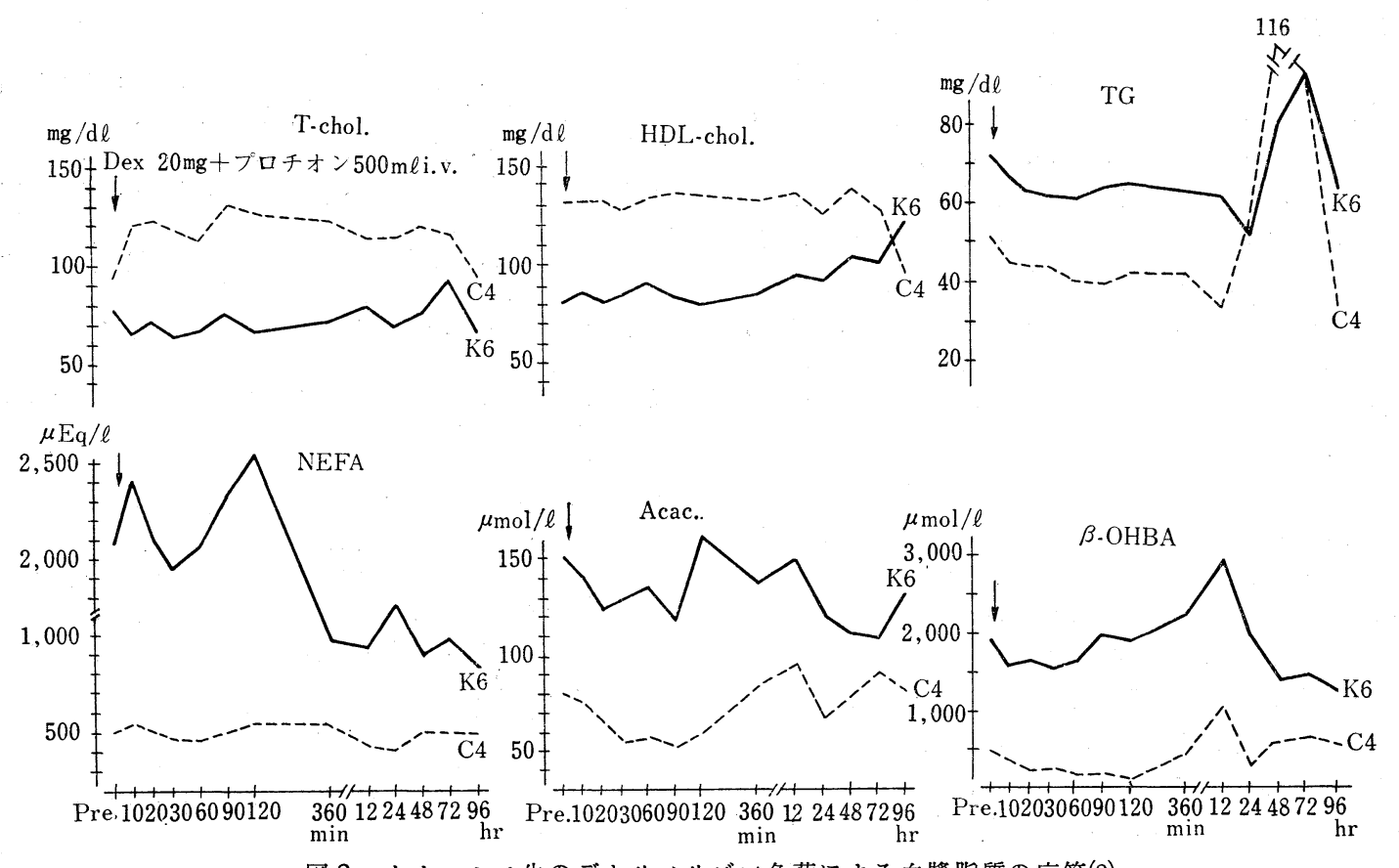

図 8 ケトーシス牛のデキサメサゾン負荷による血漿脂質の応答(2) 
K6 の血漿脂質成分は, TG が C 4 と同様な变動をし, NEFA は負荷後 20 分および 120 分に 2 峰性の上昇を示 した. $\beta$-OHBA は 12 時間後に一過性の上昇を示した が, 96 時間後には負荷前值の $60 \%$ にまで減少した. こ の時点で，尿中ケトン体はほとんど検出されなくなった (図 8).

\section{3. 考察}

近年, ケトーシスの牛に対する内分泌学的研究は, グ ルコース負荷時のインスリンの動態を中心に盛んに行わ れ,グルコース負荷後の応答パターンは健康牛と異なる ことが示唆されている11,12,14,19,25). また，分婏前後にお けるグルコースやホルモンの変動も観察4,22)されて和り, 健康牛でも分娩を契機にこれらの成分が生理的な変動を 示すことが確認されている. ヒトでは種々の内分泌失調 の診断法の一つとして, アルギニン負荷によるホルモン やグルコースの応答パターンが利用されている ${ }^{24)}$.この 方法が牛に応用できるかを試験する目的で, 今回，ヶト ーシスの牛について実施した.

ケトーシス牛における Arg. 負荷による各成分の応答 パターンは, 元井ら ${ }^{15)}$ の脂肪壊死牛の Arg. 負荷時の応 答パターンと同様に，健康牛とは異なるパターンを示す ものが多かった. しかし, ケトーシスの治瘉後では健康 牛と類似のパターンが観察されたことから, 小野 ${ }^{19)} も$ 示 唆しているよらに,ヶトーシス牛では膵の $\alpha$ および $\beta$ 細 胞の機能に異常のあることが推察された. FELIG ら², PARRILLA ら ${ }^{21)}$ は肝に和けるケトン体産生や糖新生能は, IRI とIRG の絶対量によるのではなく, 両者の比によ ると報告している. 今回, Arg. 負荷試験牛の血中 IRG/ IRI 比を求めたところ, ケトーシス牛は健康牛に比較し てその変動幅が極端に偏っていた. IRG/IRI 比と Glu., および $\beta$-OHBA との相関を求めたところ, Glu. につい ては PARRILLA ら ${ }^{21)}$ の成績と逆の結果が得られ, in vivo に拈ける糖新生は in vitro の実験よりるさらに複雑な機 構が関与しているためではないかと考劣られた. しかし， $\beta$-OHBA は過去の報告 ${ }^{21)}$ と同様に IRG/IRI 比が高いほ ど産生能が高まる傾向にあることが確認され, ケトン体 生成の抑制にはインスリンの鋭敏な反応が必要であるこ とが推察された。

つぎに,ケトーシスの一治療剤として用いられている, Dex. を利用した負荷試験に拈いて, 血漿成分の応答パタ ーンを観察したところ, Dex.のみの負荷では佐藤 ${ }^{23)}$ の報 告と同様に, Glu. は負荷後 24 時間目に著しい増加を示 したが, IRI の応答は認められなかった. また, Dex. と 糖前駆体の同時負荷試験では Glu. の増加に伴って健康 牛では IRI が鋭敏に反応を示したが，ケトーシス牛では IRI の応答が遅れ, これらの所見からも Arg. 負荷時の 結果と同様に, 膵分泌能になんらかの異常のあることが
推察された.

現在, Arg. 負荷による異常パターンの分類とケトーシ スの病態との関連, 执よび各病態に対する治療法の選択 等について例数を重ねて検討中である.

$$
\text { 文献 }
$$

1) Amstutz, H. E.: Bovine Medicine and Surgery, 539 565, American Veterinary Publication Inc. (1980).

2) 安保佳一: 牛病学, 763 776, 近 代出版, 東京 (1980).

3）安保佳一：ふお一なす, 3, 1〜7 (1983).

4) Athanasiou, V. N. and Phillips, R. W.: Amer. J. Vet. Res., 953 956 (1978).

5) Athanasiou, V. N. and Phillips, R. W.: Amer. J. Vet. Res., 957 960 (1978).

6) Baird, G. D., Heitzman, R. J., Hibbitt, K. G., et al.: Br. Vet. J., 130, $214 \sim 220$ (1974).

7) Baird, G. D., Heitzman, R. J., Hibitt, K. G., et al.: Br. Vet. J., 130, 318 326 (1974).

8) BAIRd, G. D.: J. Dairy Sci., 65, $1 \sim 10$ (1982).

9) Felig, P., Gusberg, R., Hender, R., et al.: Proc. Soc. Exp. Biol. Med., 147, 88 90 (1974).

10) Fronk, T. J., Schults, L. H. and Hardie, A. R.: J. Dairy Sci., 63, 1080 1090 (1980).

11) Hove, K. and Halse, K.: Acta. Vet. Scand., 19, 215 228 (1978).

12) Hove, K.: J. Dairy Sci., 61, 1407 1413 (1978).

13) 香本穎利, 鈴木慶信, 星野邦夫 : 第 93 回日本獣 医学会講演要旨集, 255 (1982).

14）香本穎利, 鈴木慶信, 星野邦夫, ほか：家畜診療, 240, 23〜27 (1983).

15) 元井臀子, 新林恒一, 浅野元生, ほか: 第 93 回 日本獣医学会講演要旨集, 237 (1982).

16) 本好茂一：家畜診療, 228, 36 40 (1982).

17）奥田 勝, 石井䈌宏, 星野邦夫, ほか: 第 93 回 日本獣医学会講演要旨集, 256 (1982).

18) 奥田 勝, 武石昌敬: 第 95 回日本獣医学会講演 要旨集, 238 (1983).

19）小野憲一郎：栄養生理研究会報, 24, 184 196 (1980).

20) Payne, J. M.: Metabolic Disease in Farm Animals, 156 164, International Ideas Inc., Philadelphia (1977).

21) Parrilla, R., Goodman, M. N. and Jones, C. J.: Diabetes, 23, 725 731 (1974).

22) 酒井健夫, 小倉喜八郎, 早川 徹, ほか：第 94 回 日本獣医学会講演要旨集, 190 (1982).

23）佐藤七三郎：日本獣医畜産大学紀要, 21, 154 178 (1972).

24）島 健二：内科, 37, 特集「臨床検査法の進歩一 その意義と解釈一」, 1337〜1344 (1976).

25) 矢部光広, 小倉喜八郎, 三好志郎, ほか：家畜診 療, 226, 7〜 11 (1982). 